\title{
Peningkatan Aksesibilitas “3 M-Mobile Learning” sebagai Layanan Pendidikan
}

\author{
DENI DARMAWAN \\ Kurikulum dan Teknologi Pendidikan Fakultas Ilmu Pendidikan Universitas Pendidikan Indonesia, Bandung \\ email: diestry2005@yahoo.com
}

\begin{abstract}
This study was conducted to provide a solution to the demands of providing and improving access to education and learning services as an alternative for distance learning communication for learners in South West Java. Based on the demands of service provision and improvement of education and distance learning, then a mobile learning system website which called "3M-Learning" was manufactured. Then through these products, an analysis of the number of "3M-Learning" usage was performed in order to obtain data regarding the increased accessibility of information education and learning services. The method used in producing and analyzing "3M-Learning" website system was Research and Development ( $R$ \& D) with targeted research areas include Banjar, Ciamis, Tasikmalaya, Pangandaran, Cianjur and Sukabumi. The material contained in "3M-Learning" website was partly addressed to the uses of elementary, junior high, senior high school, and university. The results of this study indicate that through the "3M-Learning" the number of active learners who accessed educational services for 6 months were able to reach 1.769 people. These results indicate that the level of educational services accessibility can be said to have good acceleration
\end{abstract}

Keyword: accessibility, mobile learning, education services.

\begin{abstract}
Abstrak. Studi ini dilakukan guna memberikan solusi atas tuntutan penyediaan dan peningkatan akses layanan pendidikan dan pembelajaran sebagai salah satu alternatif komunikasi pembelajaran jarak jauh bagi para peserta didik di wilayah Jawa Barat Selatan. Berdasarkan atas tuntutan penyediaan dan peningkatan layanan pendidikan dan pembelajaran jarak jauh ini, maka diproduksi suatu sistem website mobile learning yang diberi nama "3M-Learning". Melalui produk tersebut selanjutnya dilakukan analisis terhadap sejumlah penggunaan "3M-Learning" sehingga diperoleh informasi data mengenai peningkatan aksesibilitas layanan pendidikan dan pembelajaran. Metode yang digunakan dalam memroduksi dan menganalisis sistem website "3M-Learning" ini adalah Research and Development (R\&D) dengan sasaran wilayah penelitian mencakup Kota Banjar, Kabupaten Ciamis, Tasikmalaya, Pangandaran, Cianjur dan Kabupaten Sukabumi. Materi yang terdapat dalam website "3M-Learning" ini di antaranya tujukan bagi para user untuk jenjang SD, SMP, SMA, dan Perguruan Tinggi. Hasil penelitian ini menunjukkan bahwa melalui "3M-Learning" para pembelajar yang aktif mengakses layanan pendidikan selama 6 bulan mampu mencapai 1.769 orang. Hasil ini menunjukkan bahwa tingkat aksesibilitas layanan pendidikan dapat dikatakan mengalami percepatan dengan baik.
\end{abstract}

Kata Kunci: aksesibilitas, mobile learning, layanan pendidikan.

\section{Pendahuluan}

Wilayah Jawa Barat selatan hingga saat ini selalu tertinggal dalam bidang pendidikan, terutama layanan akses dan pemerataan program pembelajaran yang terbarukan. Hal ini terjadi mengingat jarak tempuh dan akses yang cukup jauh dari Bandung, ibu kota provinsi Jawa Barat. Dengan demikian, pemerataan layanan pembelajaran menjadi suatu yang sulit untuk berkembang. Di sisi lain, dari beberapa wilayah Jawa Barat Selatan mulai dari Banjar, Pangandaran, Ciamis, Tasikmalaya, Garut, Cianjur, dan Sukabumi, dituntut mampu meningkatkan kualitas layanan aksesibilitas layanan pembelajaran di sekolah-sekolahnya.

Jika dilihat dari pendekatan inovasi dalam pembelajaran yang dijelaskan oleh Everet $\mathrm{M}$. Rogers (2009: 118), menunjukkan bahwa salah satu indikator masyarakat inovatif ditandai dengan upaya memanfaatkan perkembangan teknologi 
yang berkembang di masyarakat. Dalam konteks penelitian ini, maka peneliti mencoba untuk menganalisis pula produk teknologi komunikasi dalam bentuk handphone yang dewasa ini semakin murah dan banyak dimiliki oleh para guru hingga ke daerah, yang diasumsikan akan mampu membuktikan pendapat dari M. Rogers tersebut.

Berdasarkan analisis kondisi eksisting tersebut maka permasalahan dalam penelitian ini berhubungan dengan konteks penelitian yang mencakup: (1) bagaimanakah membangun sistem mobile learning engine yang dapat dijadikan alternatif dalam memberikan layanan komunikasi pembelajaran jarak jauh bagi peserta didik yang berada di wilayah Jawa Barat selatan; (2) menganalisis penggunaan "3M-Learning" untuk melihat peningkatan aksessibilitas guru dan siswa dalam pembelajaran jarak jauh di Jawa Barat Selatan.

Artikel ini bertujuan untuk membangun sistem layanan komunikasi pembelajaran jarak jauh bagi peserta didik yang berada di wilayah Jawa Barat selatan. Tujuan penelitian selanjutnya yaitu menganalisis penggunaan "3M-Learning" untuk melihat peningkatan aksesibilitas guru dan siswa dalam pembelajaran jarak jauh di Jawa Barat Selatan. Sistem layanan pembelajaran tersebut dibangun dengan memanfaatkan sejumlah aplikasi software dari keilmuan Teknologi Pendidikan, khususnya mata kuliah pembelajaran berbasis komputer dan Sistem Pembelajaran Jarak Jauh dan Rekayasa Perangkat Lunak. Beberapa asumsi dalam Pengembangan "3M-Learning" sangat ditunggu oleh pihak guru dan manajemen dinas pendidikan, khususnya UPTD di wilayah Jabar selatan Banjar, Ciamis, Tasikmalaya, Garut, Cianjur, dan Sukabumi, mengingat jangkuan atau akses ke kota kabupaten cukup jauh, sehingga bahan ajar dan layanan pembelajaran harus ditangani oleh guru, termasuk kebijakan lainnya.

Perencanaan pengembangan "3M-Learning", pada dasarnya telah dimulai dengan melakukan pemetaan ke sejumlah sekolah dan guru yang hingga saat ini telah dibekali teknis untuk membuat bahan ajar "3M-Learning", khususnya dari wilayah Kabupaten Garut Selatan. Tahapan penelitian ini telah dilakukan secara meluas dalam jangka waktu 1 bulan pembekalan, 1 bulan teknis instalasi jaringan, dan 2 bulan implementasi dalam proses pembelajaran seiring dengan berjalannya PBM di sekolah-sekolah sasaran penelitian. Mitra Industri yang telah mendukung pengembangan "3M-Learning" ini adalah PT. Telkom, mengingat produk handphone yang sudah murah, kemudian akses sinyal yang kuat akan menjadi dukungan dan kebutuhan pokok dalam riset ini, terutama dalam melangsungkan keberlanjutan, pemanfaatan serta penyebarluasan produk hingga mampu dimanfaatkan oleh semua guru dan siswa.
Jika dilihat dari upaya penyelesaian kebutuhan layanan akses, mutu dan keterbacaan bahan ajar dalam rangka pemecahan masalah belajar di era global ini, maka penelitian ini berupaya untuk mengintegrasikan sejumlah prosedur, peralatan, analisis layanan, dan bentuk pembelajaran dengan karakteristik yang berbeda. Upaya ini sebagaimana dijelaskan dalam salah satu kajian e-learning modern menurut Anita Rosen, (2009:28) bahwa, Over the past 25 years, the technology sector has seen many new trends and technologies move from rough concept to delivered products and then to new business approaches. In all cases, organizations go through five stages when assimilating the new trends and technologies into the way they do business, there are: (1) Denial; (2) Outsourcing; (3) PowerPoint; (4) Execution and (5) Integration. Selain itu, mitra swasta dalam hal ini Pesantren Al-Manar, Kecamatan Pameungpeuk, telah mampu mendukung layanan produksi bahan ajar, training, dan uploading akses bahan ajar langsung dari daerah. Demikian juga dengan dukungan Laboratorium Teknologi Pendidikan UPI yang telah melatih pengelola bahan ajar di tingkat UPTD dengan dukungan virtual laboratoriumnya. Termasuk juga Laboratorium IT STKIP Kabupaten Garut, UNSIL, UMMI, serta PGRI Kecamatan Ciamis, dan juga ICT Center Kabupaten Garut, Ciamis, Tasikmalaya, serta Sukabumi, telah mendukung diseminasi "3M-Learning" ini. Waktu Penelitian dilaksanakan selama 6 bulan dengan dasar pemikiran estimasi pengumpulan data paparan berupa aspirasi dari subjek penelitian, masa desain, masa pengembangan, dan masa uji coba serta implementasi model "3M-Learning" yang dihasilkan. Mobile Learning yang dibutuhkan untuk melayani pembelajaran virtual diharapkan mampu terpenuhi melalui pembelajaran virtual dengan dukungan sistem lainnya, sebagaimana dikemukakan oleh Ruth Calvin Clark and Richard E. Mayer (2008: 11) bahwa most virtual classroom tools incorporate similar functions, although the screen interfaces may differ.

Tulisan ini menggunakan metode penelitian R \& D (Research and Development) menurut Gall, Meredith Damien \& Borg Wolter, R,(2009:784785), yaitu terdiri atas 10 langkah pokok yang akan dipetakan ke dalam waktu 6 bulan, yaitu; (1) penelitian dan pengumpulan informasi kesiapan guru, sekolah, UPTD, dan ICT Center Kabupaten; (2) perencanaan sistem jaringan "3M-Learning"; (3) pengembangan model tahap satu dalam bentuk penyusunan bahan ajar "3M- Learning" dan prototife engine, serta webserver "3M-Learning"; (4) uji coba lapangan tahap satu; (5) revisi model tahap satu; (6) uji coba model operasional hasil revisi pada beberapa sekolah sasaran (melatih guru); (7) revisi model operasional; (8) uji coba lapangan model operasional secara lebih luas ke semua sekolah yang ada di UPTD 5 kabupaten jabar selatan; (9) revisi model operasional hasil uji coba di 5 kabupaten sebagai 
model final; dan (10) diseminasi dan implementasi model "3M-Learning". Penelitian ini direncanakan dilakukan dalam 6 bulan-1 tahun. Jadwal yang diadaptasi dari tahapan riset tersebut dimodifikasi berdasarkan tahap penelitian per triwulan sesuai dengan target luaran yang dihasilkan.

Subjek penelitian adalah para mahasiswa dan guru yang merupakan calon pengguna dari "3M-Learning" yang akan dikembangkan oleh tim peneliti. Dalam penelitian ini, instrumen pengumpul data berupa daftar record yang disediakan pada website "3M-Learning" yang akan dibangun. Di mana teknik analisis datanya dilakukan dengan cara mendeskripsikan para responden penelitian (user website mobile learning) yang kemudian dijadikan dasar dalam proses desain dan pengembangan lebih lanjut oleh tim peneliti.

Berikut adalah rancangan penelitian yang telah disesuaikan dengan pendekatan penelitian di atas, yaitu sebagai berikut:

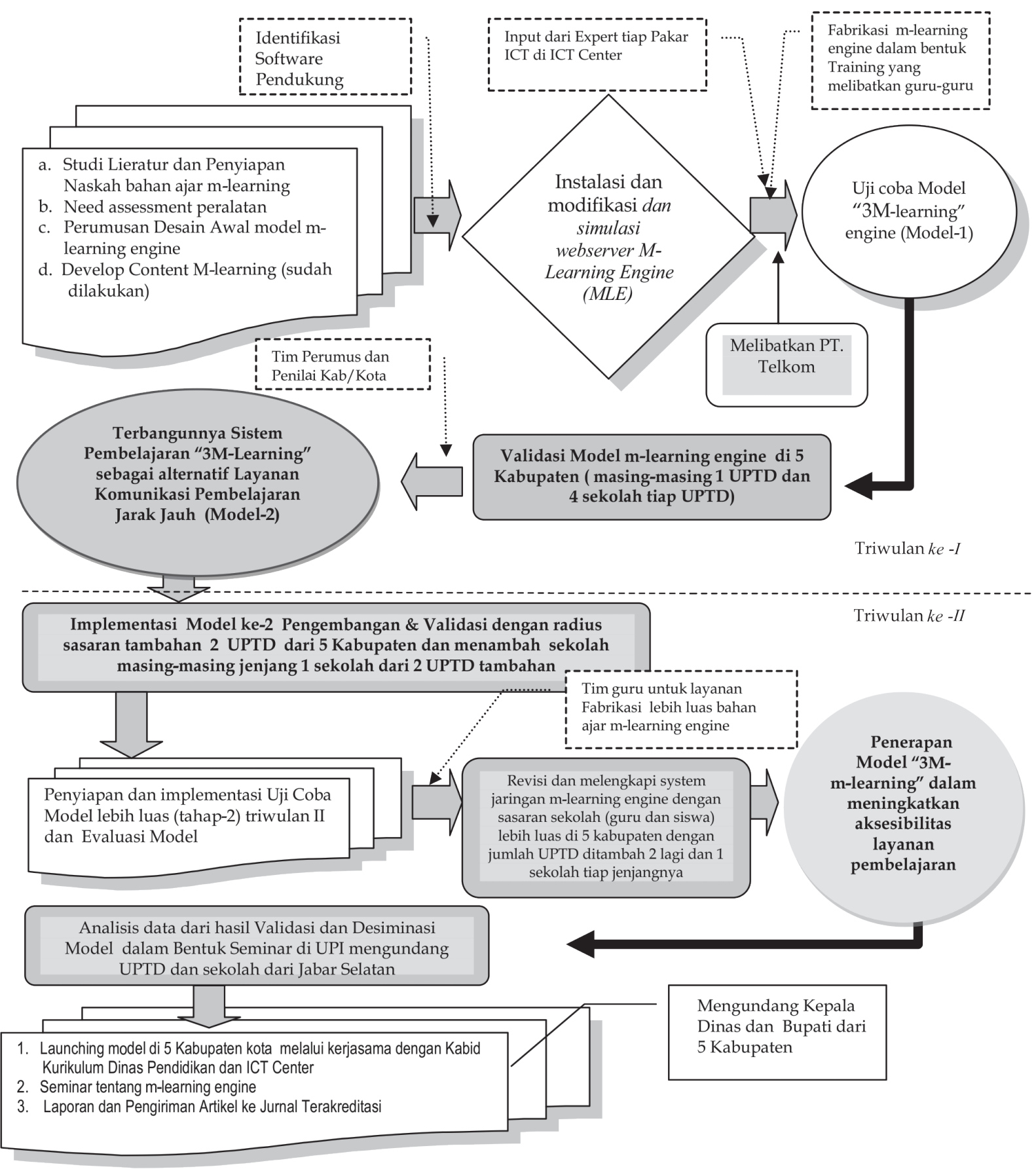

Gambar 1

R\&D "3M M-Learning" sebagai Layanan Pendidikan di Jawa Barat 


\section{Analisis Kebutuhan dan Tahapan produk- si Mobile Learning}

Pengembangan "3M-Learning" ini akan dilakukan dengan metode riset dan pengembangan terhadap dua besaran produk, pertama, yaitu membangun infrastruktur jaringan (website, dan center "3M-Learning" di ICT Center kab/kota masing-masing wilayah sasaran), dan kedua, yaitu mengembangkan sejumlah bahan ajar "3M-Learning" yang siap dimanfaatkan oleh semua guru pada semua jenjang pendidikan yang relevan dan memiliki karakteristik dapat diproduksi dalam bentuk "3M-Learning". Setelah kedua besaran pembangunan teknologi ini baru dilakukan diseminasi dalam bentuk training, dan penyebarluasan secara roadmap oleh peserta training (guru-guru tutor) perwakilan dari semua kabupaten sasaran penelitian kepada seluruh sekolahnya.

Dari beberapa uji coba mengembangkan bahan ajar "3M-Learning" oleh Jurusan melalui dosen mata kuliah Kecerdasan Buatan menunjukkan data bahwa ternyata fenomenanya cukup baik diterima di lapangan. Lebih jauh bahkan guru-guru mendukung untuk segera dikembangkan secara formal dengan payung kebijakan dari Kepala Bidang Kurikulum Dinas Pendidikan Kab/Kota sasaran riset ini. Untuk memperkuat kejelasan dari pentingnya produk penelitian ini, berikut adalah beberapa hasil pemikiran penting dalam pengembangan keilmuan Teknologi Pendidikan dalam bentuk desain, perancangan, penyebarluasan produk akademik "3M-Learning" secara lebih luas dan strategis, yaitu dimulai dari pengumpulan informasi kesiapan guru, sekolah, UPTD, dan ICT Center Kabupaten, pada tahapan ini beberapa guru yang berjumlah 32 orang yang mewakili 5 sekolah berdiskusi dengan tim peneliti untuk merumuskan desain pengembangan konten "3M-Learning" dan sistem engine yang mendukungnya. Dalam tahapan ini, peneliti mengadopsi dan mengimplementasikan pendapat dari Gibson, David, Clrack Aldrich, and March Prensky (2007: 225) mengenai connecting teaching and learning yang menyatakan bahwa

\begin{abstract}
"connecting teaching and learning" is demonstrated through the construction of a Teacher Work Sample (TWS). A TWS has several components including: (1) a description of the school, classroom, and community setting; (2) the targets for learning mapped to local, state, and national goals and benchmarks for student learning; (3) a series of lesson plans designed to move all students toward these learning targets; (4) a pre-assessment used to determine the prior skills, knowledge, and interests of the students; (5) a description of the modifications or individualizations necessary to ensure that all students reach the learning targets; (6) a post-assessment and data analysis section examining individual student learning, and; (7) reflections on teacher effectiveness and teacher professional development needs. As each of these products are constructed and represented together, they make-up a TWS. However, these products are not the goal of the process of teacher work sample methodology.
\end{abstract}

Setelah dirumuskan, maka tahapan pengembangan kedua adalah tahapan perencanaan sistem jaringan "3M-Learning" setelah perencanaan ini selesai selanjutnya penelitian dilanjutkan pada tahapan pengembangan model-1dalam bentuk penyusunan bahan ajar "3M-Learning" dan prototife engine, serta webserver "3M-Learning" dengan memanfaatkan sejumlah software aplikasi dan pemograman webased design seperti terlihat pada gambar 2.

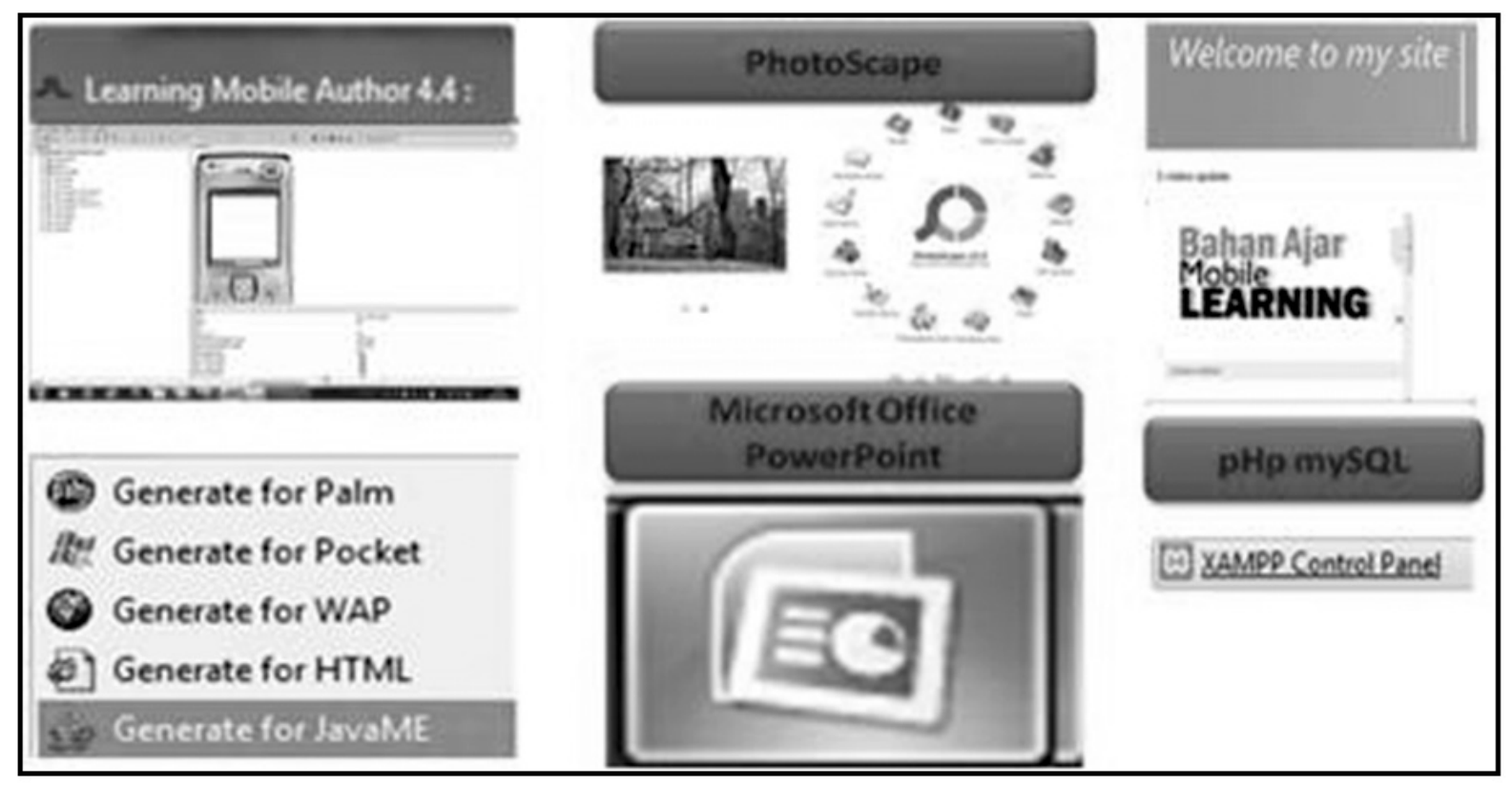

Gambar 2

Software Aplikasi dan Pemograman Pembangun Sistem "3M-Learning" 
Pada Gambar 2, menunjukkan software Learning Mobile Author versi 4.4, yang merupakan software pembangun tahap akhir yang memerlukan bahan input dari software pengolah image yaitu software Photoscape yang merupakan software pengolah ukuran image. Software ini memerlukan inputdari software aplikasi kelompok microsoft office power point, yaitu software untuk membuat bahan presentasi materi yang selanjutnya akan di konversi dalam bentuk image. Sedangkan software untuk membangun laman web mobile learning dalam penelitian ini, yaitu menggunakan bantuan Xampp, dan PHP mySQL. Hasil dari tahap pengembangan di atas maka sistem "3M-Learning" dapat dibangun sebagai model-1.

Setelah terbangun sistem engine dengan beberapa bahan ajar mobile yang diunggah dalam web mlearning di atas, maka dilakukan tahapan selanjutnya, yaitu tahapan uji coba lapangan tahap awal. Dari hasil uji coba ini selanjutnya diperoleh masukan dari beberapa orang guru mengenai berbagai hal yang berkenaan dengan dieain web "3M-Learning" yang harus independent dan dinamis. Demikian juga dengan aspek konten materi pelajaran yang disajikan, sebagaimana dijelaskan dalam Educational Technology: promise unfulfilled dari Thomson (1990) dalam Willer Martin (2002:9), yang menjelaskan bahwa Now famous The No Significant Difference Phenomenon compiled all the studies that compared modes of delivery: for example, distance versus classroom, and online versus face to face. The overwhelming conclusion was that the mode of delivery made no difference to student performance, so it is the content and not the medium that seems to be important.

Adapun hasil uji-revisi pada tahapan ini dapat dilihat pada gambar 3.

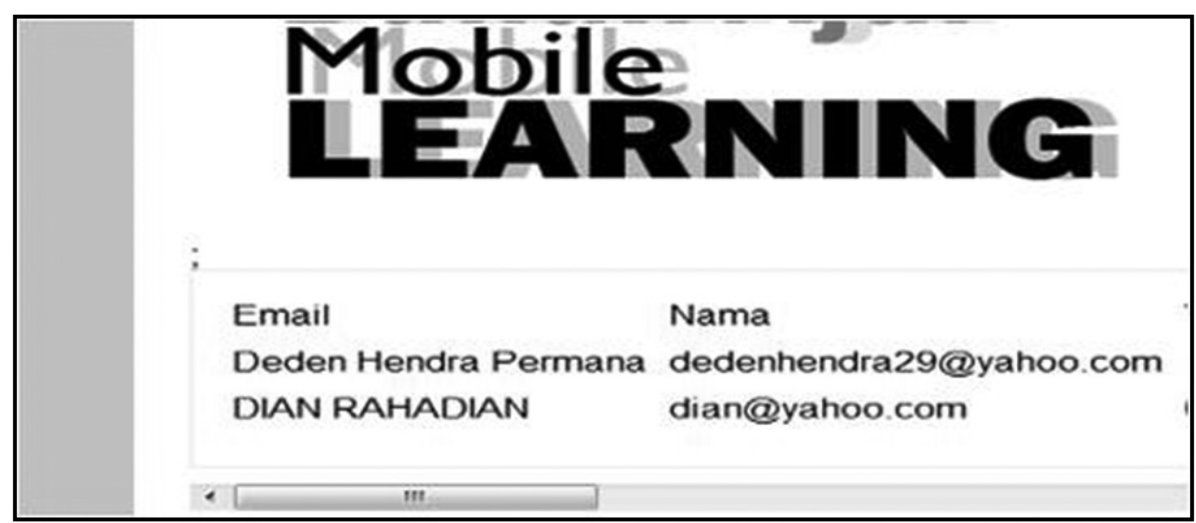

Gambar 3

Tampilan User pada Model Tahap Awal Sistem "3M-Learning" Hasil Revisi

Pada Gambar 3 di atas terlihat model tahap kedua hasil revisi sebelumnya yang sudah menunjukkan adanya identitas berupa header website mobile learning. Sebagai penyempurnaan dari websebelumnya, maka untuk fasilitas pengguna atau user telah disediakan berupa form nama dan form untuk alamat email. Selanjutnya, dari hasil revisi di atas peneliti melakukan revisi model dan mengujicobakannya kembali hingga diperoleh model hasil revisi dari model tahap awal di atas, yaitu seperti tampak pada gambar 4.

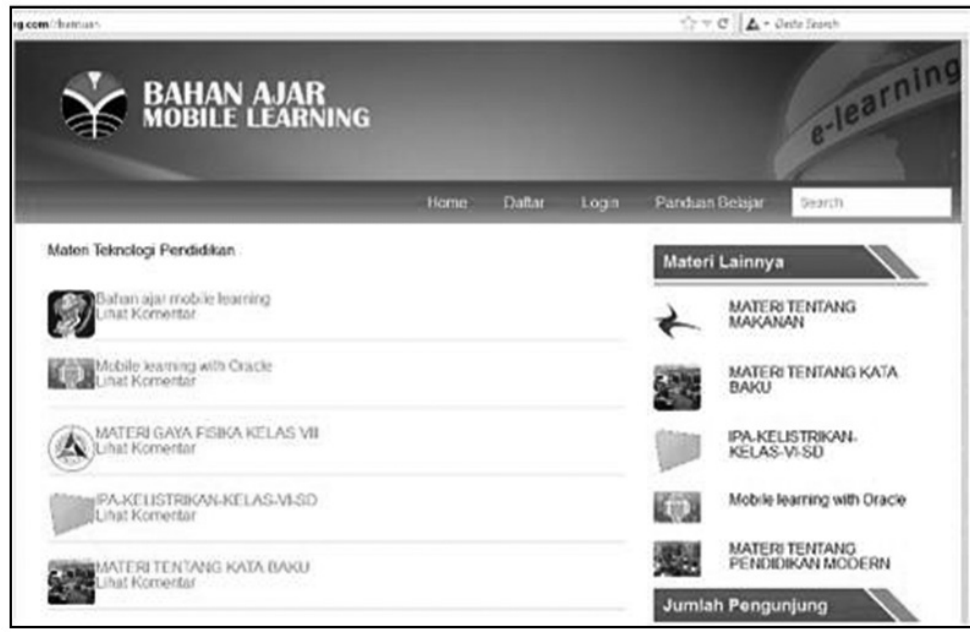

Gambar 4

Model Revisi Tahap Awal dari Website "3M-Learning" 
Pada gambar 4 di atas menunjukkan bahwa website mobile learning yang dikembangkan telah memiliki sejumlah fasilitas yang lebih lengkap dari model sebelumnya. Dapat dilihat pada Gambar 4 di atas menunjukkan bahwa laman web utama atau portal utama dari website mobile learning sudah menyediakan fasilitas menu fulldown yang cukup lengkap, yaitu menyediakan menu Home, Daftar, Login, dan Panduan Belajar. Demikian juga dengan headersudah lebih komunikatif, yaitu menunjukkan identitas sebagai sebuah halaman website mobile learning dengan efek image maupun teks yang cukup memberikan kejelasan sebagai identitas laman website mobile learning.
Pengembangan model dilakukan sampai menghasilkan Model uji coba terbatas sesuai dengan tahapan penelitian pada triwulan ke-1. Model uji coba terbatas ini selanjutnya, dikembangkan lagi dengan terlebih dahulu melalui revisi dan uji coba pada beberapa guru dan sekolah sesuai dengan desain penelitian. Selanjutnya, hasil uji coba tersebut dijadikan masukan revisi khususnya pada beberapa fitur dan fasilitas yang lebih sempurna untuk website mobile learning. Setelah hasilnya lebih sempurna maka website mobile learning tersebut digunakan oleh sejumlah user sehingga informasi hasil dari uji coba tersebut record-nya dapat dilihat pada gambar berikut di bawah ini.

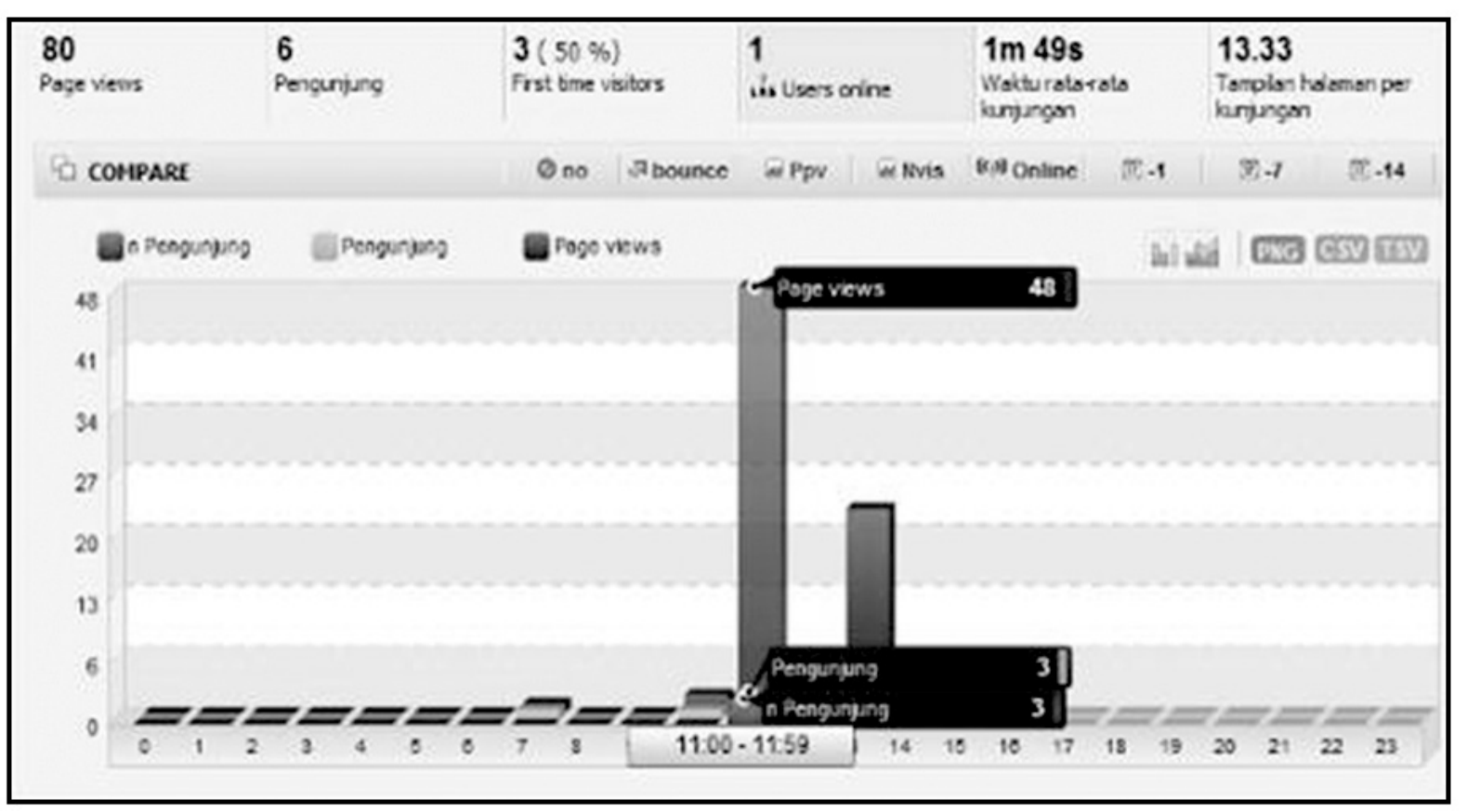

Gambar 5

Record Pengguna Berdasarkan Model Uji coba Terbatas dari Website "3M-Learning"

Pada Gambar 5 di atas dapat dibaca untuk informasi grafik yang menunjukkan angka untuk Page Views sebanyak 48 orang, kemudian grafik pengunjung sebanyak 3 orang. Adapun pada bagian kiri atas menunjukkan page views sebanyak 80 orang, artinya bahwa website tersebut selama uji coba terbatas telah dikunjungi oleh user sebanyak 80 orang. Dari hasil rekaman di atas, semua pengguna telah memberikan masukan untuk pengembangan model selanjutnya atau disebut model uji coba terbatas. Adapun revisi yang dilakukan selama penelitian ini dilakukan pada beberapa fitur atau fasilitas untuk user, sehingga memberikan kemudahan mengakses dan mengunduh sejumlah bahan ajar mobile learning.
Fenomena peningkatan akses pada tahapan uji coba ini tidak terlepas dari kemampuan individu (guru) sebagai user yang mampu mengoptimalkan kerja otak kiri dan kanannya dalam upaya menyeimbangkan kebutuhan bahan ajarnya, di mana penyeimbangan itu terjadi ketika ia memilih simbol dengan gambar tertentu dan membaca judul atau teks dari simbol materi yang disajikan pada website tersebut sebagaimana dijelaskan oleh Deni Darmawan (2010: 188) dalam kajian biologi komunikasi menegaskan bahwa dalam Brain Communication dan Neurologi Communication, yaitu ilmu komunikasi yang mengkaji mengenai proses komunikasi yang terjadi di dalam otak manusia berdasarkan struktur dan jaringannya. Demikian 


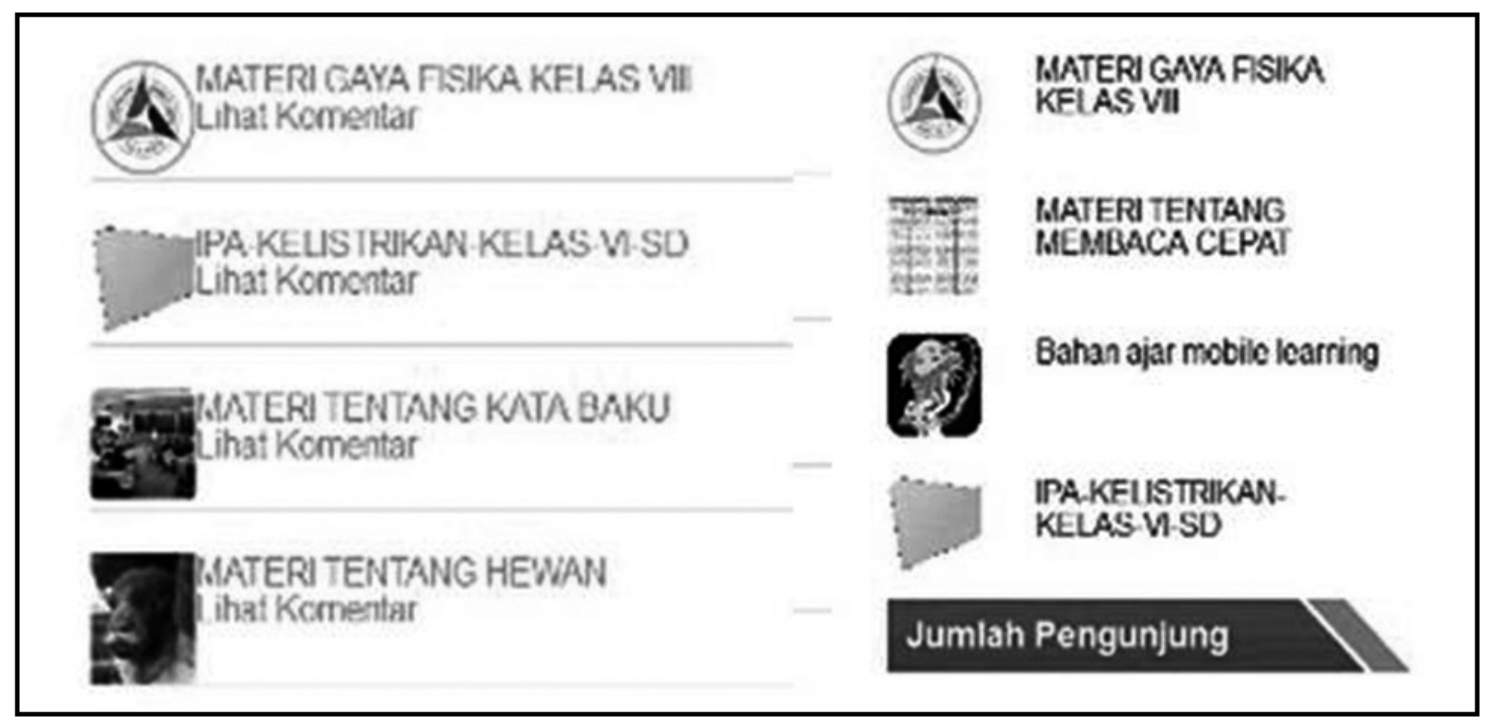

Gambar 6

Model hasil Uji coba dan Revisi Model Terbatas dari Website "3M-Learning"

juga bagi pengelola dilakukan penyempurnaan fasilitas pengunggahan bahan ajar mobile learning.

Berikut adalah salah satu tampilan dari hasil revisi model terbatas untuk penyempurnaan fasilitas unggah bahan ajar dan fasilitas tambahan lainnya berupa informasi dan simbol jenis bahan ajar mobile learning yang mampu menyeimbangkan kerja otak kiri dan otak kanan user.

Dari gambar 6 tersebut terlihat bahwa kelompok materi pembelajaran sebagai bentuk pesan komunikasi pembelajaran jarak jauh cukup bervariasi dan ditujukan guna memberikan upaya pemenuhan materi pembelajaran yang sulit dicerna dalam pembelajaran di kelas. Kelompok-kelompok materi yang mencakup topik-topik pilihan dan memang tepat dikembangkan dan disajikan serta disampaikan secara online telah dilakukan oleh peneliti sehingga peserta didik dapat terlayani.

Temuan ini dapat dijadikan bahan dalam upaya menegaskan kembali kaitan dan dukungan antara proses pembelajaran dengan proses komunikasi, yang di antaranya memiliki kesamaan konteks mengenai isi pesan dan tujuannya. Pemikiran atas temuan ini penjelasannya sebagaimana dikemukakan Robert G. Powel and Dana L. Powel (2010: 26) bahwa "Our definition of communication states that people act upon the meanings they construct. Our view of learning follows from our definition of communication". Dengan demikian desain dan pengembangan konten dalam bentuk materi pelajaran yang dilakukan dalam penelitian ini dapat menjadi suatu peluang untuk mewujudkan kualitas isi dari proses komunikasi pembelajaran jarak jauh.

Adapun kelompok topik materi pembelajaran yang dikemas secara mobile ini diproduksi melalui software Learning Mobile Author Versi 4.4 dengan dukungan software pengembang bahan ajar dalam bentuk gambar melalui PhotoScape versi 5.0. Produksi dilakukan oleh peneliti yang melibatkan para pendidik, sehingga materi yang dipilih betulbetul sesuai dengan kebutuhan peserta didik. Sebagai contoh bahwa kekurangan pembahasan materi kelompok eksakta dan sosial yang susah dikomunikasikan oleh para pendidik, ternyata melalui fasilitas website "3M-Learning" yang dihasilkan dalam penelitian ini dapat dilakukan dengan efektif bersama-sama antar pendidik. Demikian pula upaya mengomunikasikannya kepada peserta didik dapat dengan mudah pula dilakukan secara serempak dan cepat melalui akses handphone yang mereka miliki.

Proses desain dan pengembangan, baik dalam bentuk website maupun dalam bentuk isi materi pelajaran, keduanya dilakukan guna memberikan kemudahan akses dan layanan pendidikan yang lebih merata di wilayah sasaran penelitian. Dalam perkembangannya, tidak menutup kemungkinan bahwa produk penelitian ini dapat diakses oleh para pendidik dan peserta didik di luar sasaran penelitian ini, yaitu dari luar wilayah Jawa Barat.

\section{Implementasi Model "3M-Learning" bagi Masyarakat Jawa Barat Selatan}

Dari model terbatas tersebut selanjutnya dilakukan uji coba lebih luas pada sejumlah sekolah dari 2 kabupaten tambahan di mana jumlah guru yang dikondisikan untuk mengakses diharapkan lebih banyak. Adapun hasil dari record terhadap sejumlah guru selama proses uji coba model lebih luas, sehingga diperoleh rekaman data sebagaimana terlihat pada Gambar 7. 


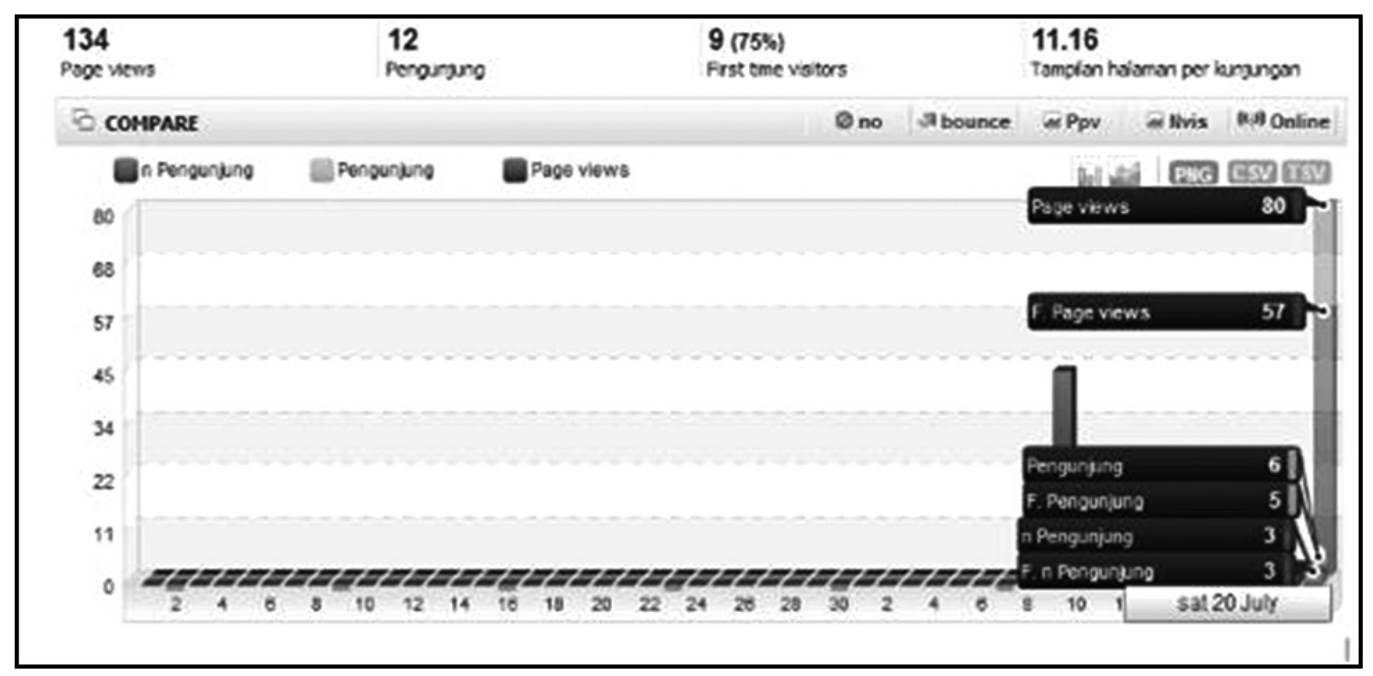

Gambar 7

Hasil Uji coba Model Lebih Luas dari Website " 3M-Learning"

Dari hasil uji coba tersebut kemudian peneliti melakukan revisi pada beberapa aspek, khususnya untuk fasilitas modifikasi Login dan Password bagi pengguna atau para guru, tahapan ini merupakan tahapan akhir dari rangkaian Research and Development $(R \& D)$. Hasil dari uji coba model lebih luas ini peneliti sebut sebagai model operasional atau model final, yang selanjutnya digunakan untuk proses layanan pembelajaran mobile pada sejumlah guru dengan wilayah kabupaten sasaran yang sempurna, sebagaimana yang telah didesain yaitu melibatkan guru-guru dari Kota Banjar, Kabupaten Ciamis, Kabupaten Tasikmalaya, Kabupaten Garut, Kabupaten Sukabumi, dan Kabupaten Cianjur.

Proses penggunaan sistem engine dalam bentuk website "3M-Learning" ini berlangsung hingga bulan k-5 sesuai tahapan jadwal penelitian. Adapun hasil record atas sejumlah user terhadap model operasional website mobile learning hasil dari penelitian ini dapat dilihat pada gambar 8. Proses monitoring dan evaluasi terhadap pemanfaatan model "3M-Learning" di atas terus dipantau hingga diperoleh peningkatan pengguna pada triwulan terakhir sebagai bahan bagi peneliti untuk menetapkan aspek kestabilan dari sistem yang dibangun. Hasil dari tahapan ini adalah model final dari sistem engine "3M- Learning" yang dibangun. Adapun rekaman jumlah pengguna berdasarkan model final ini dapat dilihat pada rangkaian gambar 8 .

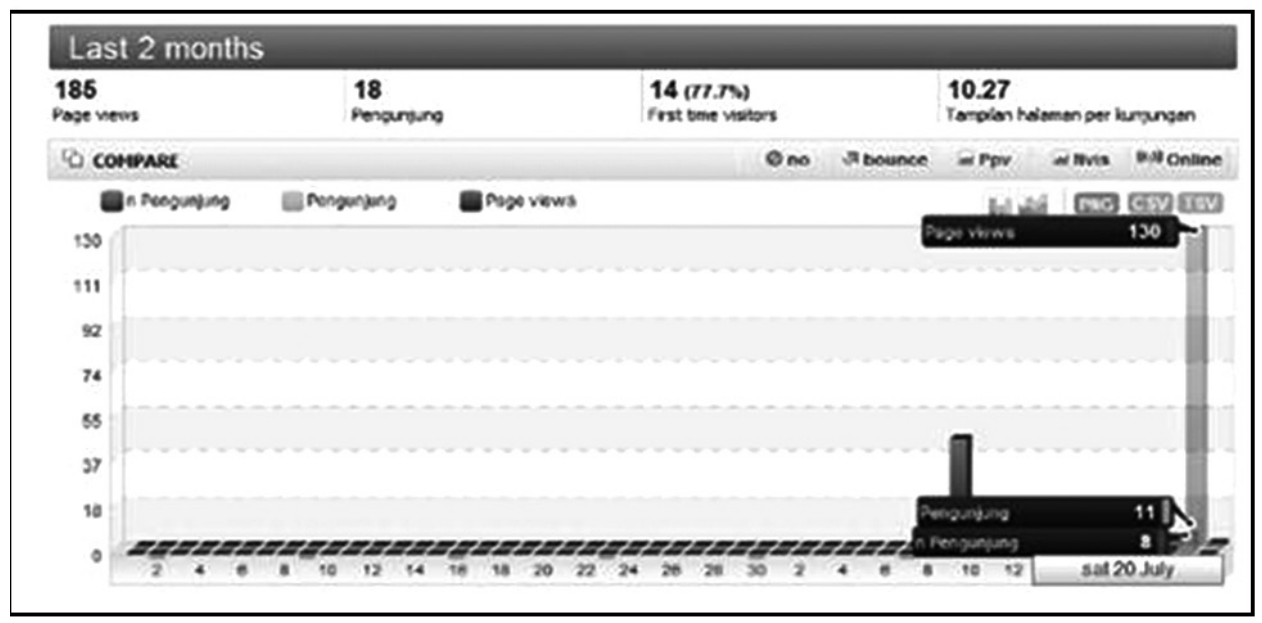

Gambar 8

Record Hasil Uji coba Model Operasional dari Proses Implementasi Model "3M-Learning". 


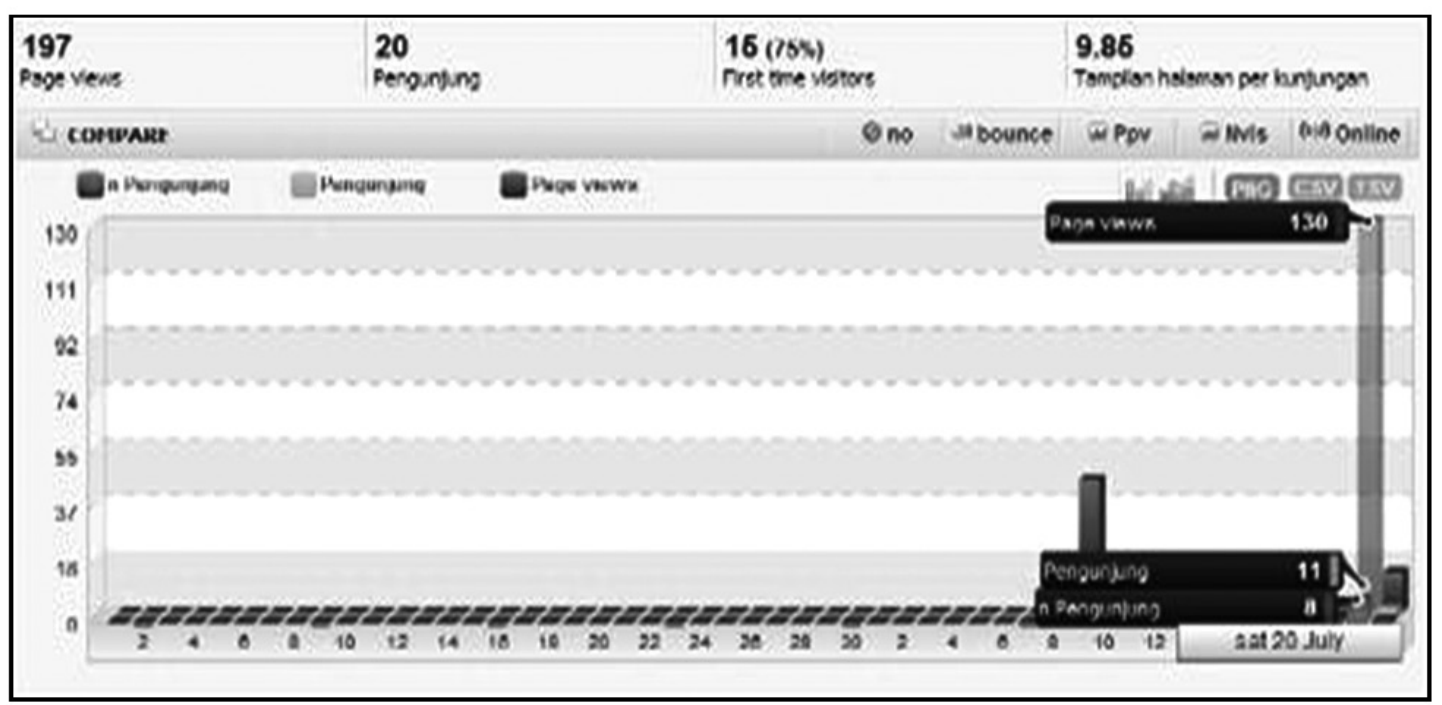

Gambar 9 (a)

Record Hasil Uji coba Model Final (Implementasi) Model "3M-Learning"

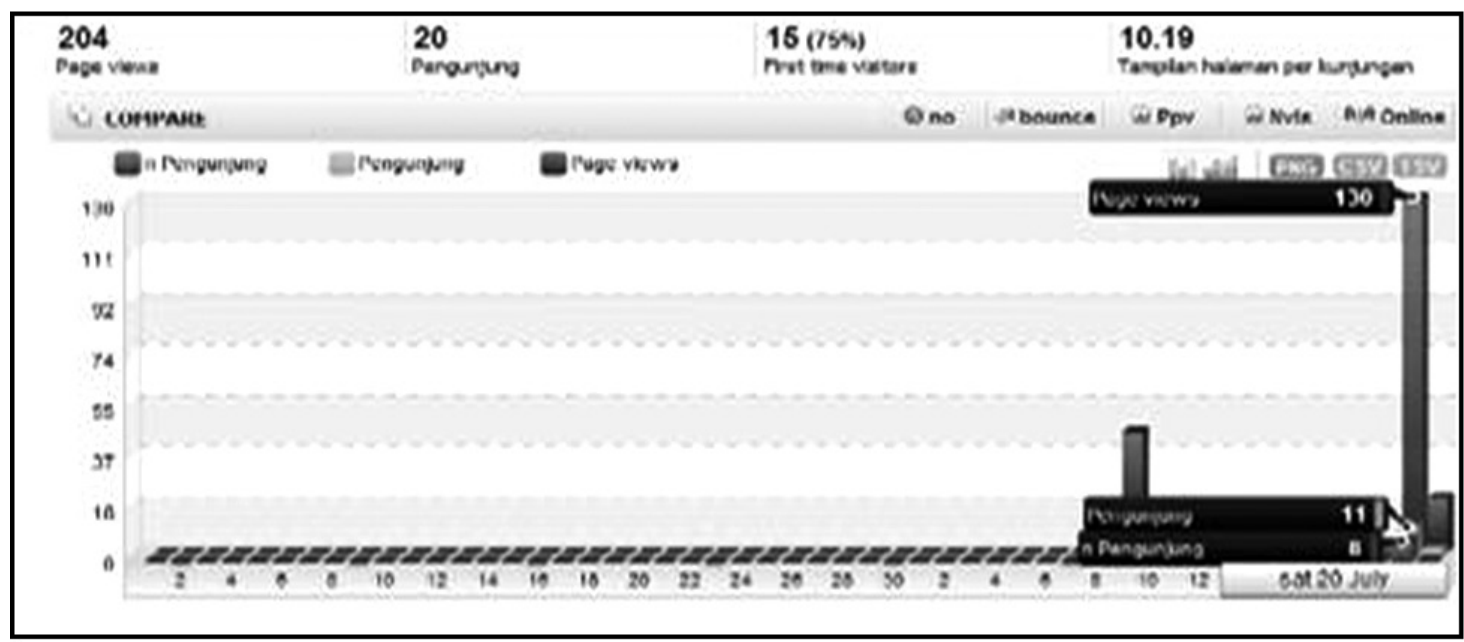

Gambar 9(b)

Record Hasil Uji coba Model Final (Implementasi) Model 3M-Learning

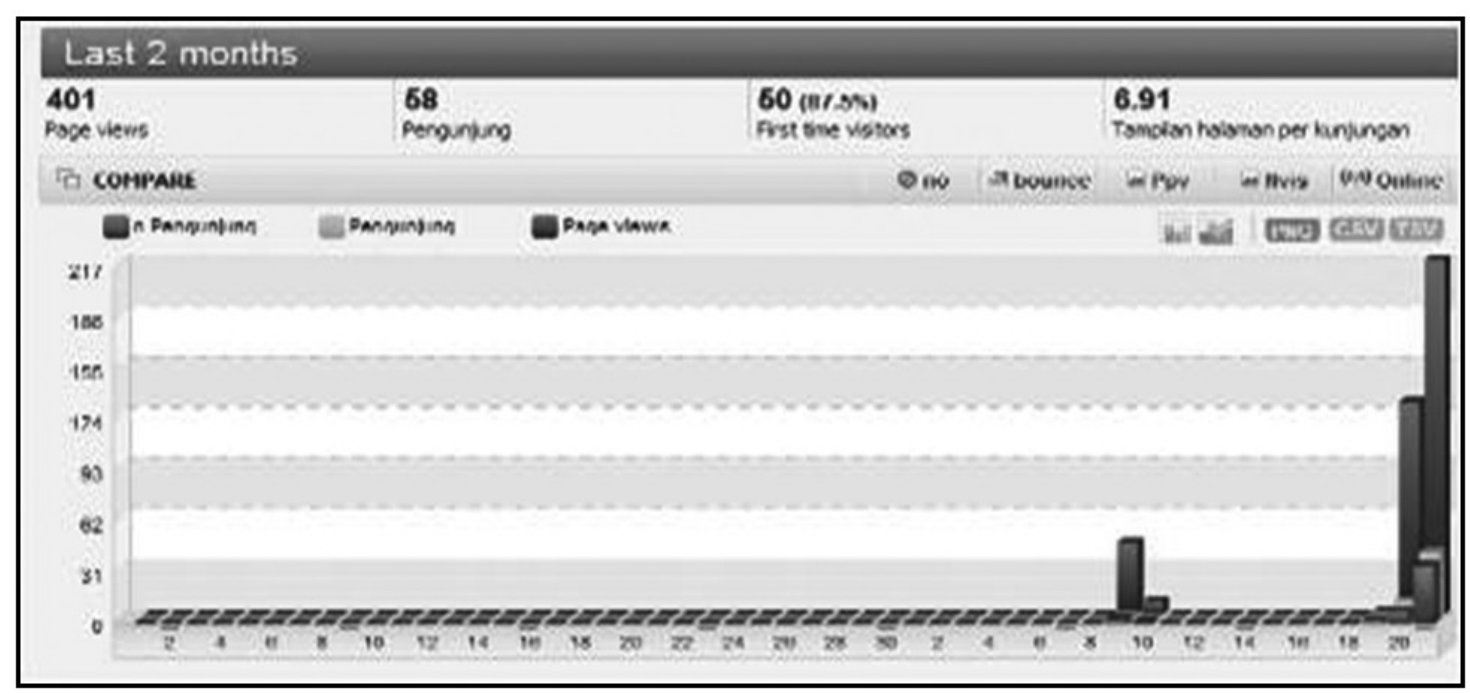

Gambar 10

Hasil Record Model Final (implementasi) Model "3M-Learning" pada triwulan ke-II 
Dari ketiga gambar di atas menunjukkan bahwa jumlah pengguna dari website mobile learning dengan nama "3M-Learning" ini semakin bertambah mulai dari Gambar 9(a) menunjukkan bahwa pengguna berjumlah 130 pada saat website dilihat ternyata total pengguna saat itu adalah 197 orang. Pada gambar 9(b), jumlah pengguna menjadi bertambah yaitu sebanyak 240 orang. Kemudian pada gambar 10, jumlah pengguna menjadi 401 orang. Peningkatan jumlah pengguna ini disebabkan oleh semakin menarik, mudah, dan lengkapnya bahan ajar mobileyang disediakan pada website tersebut dan dengan mudah dapat diunduh oleh mereka, terutama pengguna yang berstatus guru. Untuk mengontrol aspek keterpakaian sistem "3M-Learning" yang dibangun maka peneliti merangkum jumlah frekuensi user pada seluruh tahapan penelitian ini hingga diperoleh data para pengunjung dan pengguna yang cukup banyak, sebagaimana terlihat pada Gambar di bawah ini.

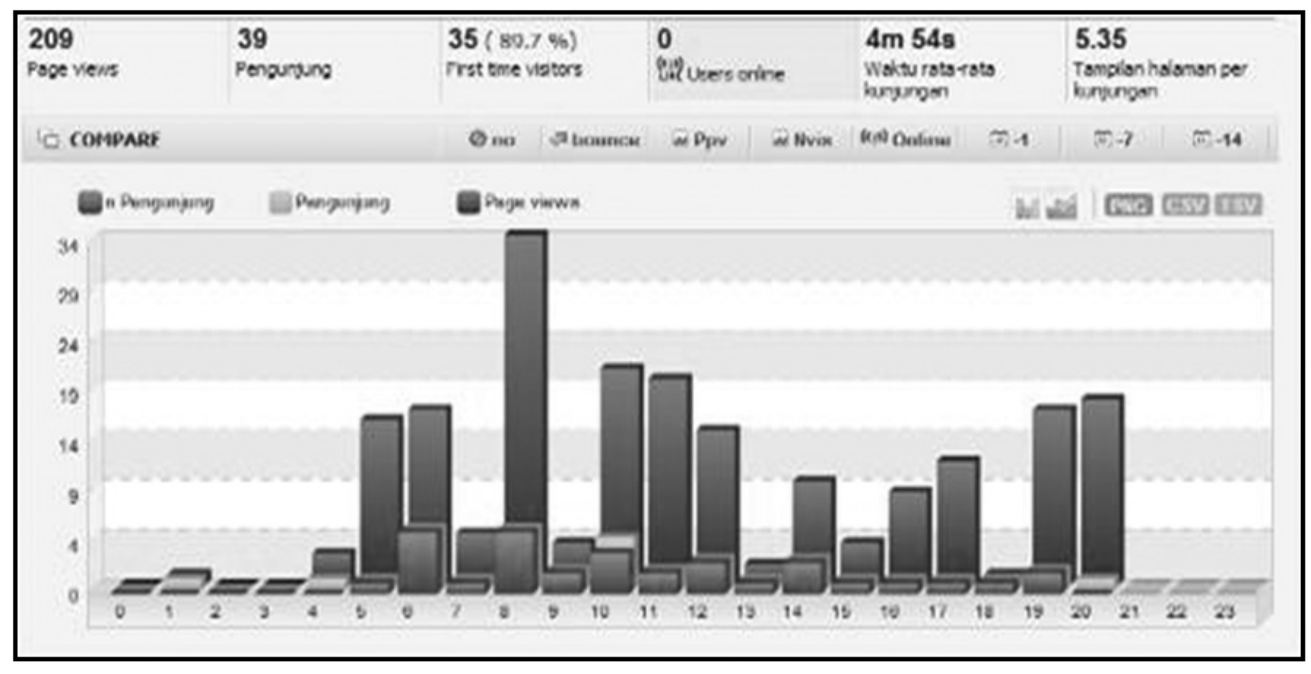

Gambar 11(a)

Record (1) Pemanfaatan Model Final "3M-Learning"

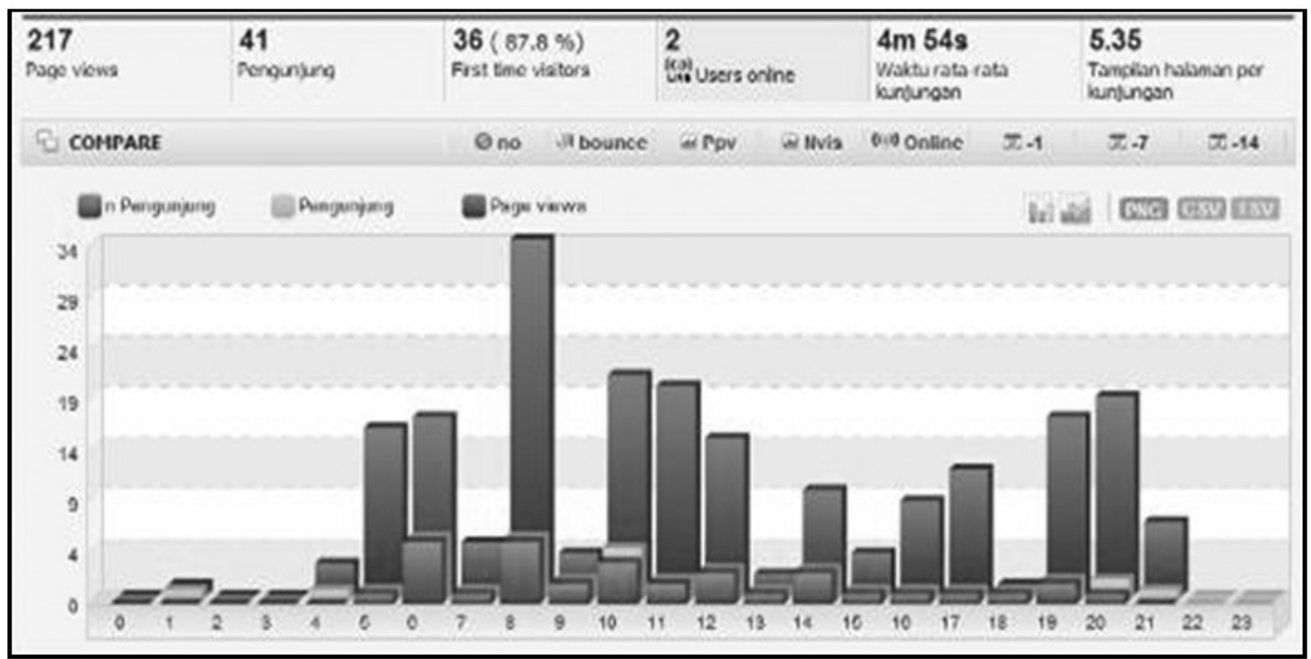

Gambar 11(b)

Record (2) Pemanfaatan Model Final "3M-Learning"

Dari Gambar 11(a) terlihat jumlah pengguna dari website mobile learning ini mencapai total berjumlah 209 orang, sedangkan pada saat website tersebut dilihat maka jumlah pengunjung yang sedang mengakses website tersebut berjumlah 39 orang. Dari data pada Gambar 11(a) tersebut ternyata terus bertambah sebagaimana terlihat pada Gambar 11(b), yaitu mencapai total 217 orang pengguna dan yang sedang mengakses saat itu berjumlah 41 orang. Dengan demikian, dari kedua gambar grafik di atas terlihat adanya peningkatan grafik jumlah pengguna yang cukup signifikan. Temuan ini mampu menjawab apa yang dikemukakan oleh White Paper (2012: 13) dalam Ericom Software tentang makna dalam pengembangan mobile learning hendaknya memerhatikan pernyataan bahwa The manageability 
aspect of supporting mobile devices is one of the easier challenges to work around.

Ketersediaan akses pembelajaran secara online dan juga dapat dimanfaatkan secara mobile melalui perangkat handphone para pendidik seperti guru, dosen akan memberikan kemudahan akses dan pemenuhan kebutuhan akan pengetahuan dan informasi lainnya secara cepat oleh para peserta didik. Temuan-temuan selama proses pengembangan dan peningkatan jumlah pengakses terhadap produk penelitian ini menunjukkan bahwa layanan pendidikan sudah saatnya mampu memanfaatkan hasil inovasi yang cepat. Secara khusus, inovasi-inovasi yang dibutuhkan dalam bidang layanan atau penyelenggaraan pendidikan dalam bentuk online sebenarnya telah tersedia dan banyak yang gratis. Sebagaimana dalam temuan penelitian ini inovasi dilakukan dalam bentuk sistem dan software yang murah dan mudah dimanfaatkan. Sebagaimana yang telah dibahas pada tahapan proses pengembangan website"3M-Learning" dalam penelitian ini maka pihak pengembang telah mampu memanfaatkan software "View Online Statistics Record" yang secara otomatis dapat diintegrasikan dalam website yang telah dikembangkan.

Dalam konteks komunikasi pembelajaran jarak jauh yang melibatkan para aktor komunikasi, seperti peserta, didik maka perannya akan sangat menentukan keberhasilan pembelajaran itu sendiri. Dalam hal ini faktor desain komunikasi menuntut aktivitas belajar peserta didik dan merupakan komponen pokok yang harus terus dikembangkan. Secara tegas aktivitas peserta didik ini telah dijelaskan pada temuan penelitian pada tahap desain dan pengembangan materi pembelajaran, sehingga fenomenanya mampu meningkatkan jumlah pengguna website "3M-Learning" dari waktu ke waktu. Untuk menyelaraskan temuan ini, maka Robert G. Powe dan Dana L. Powel (2010:25-
26) menegaskan kembali bahwa "Students are active agents in the creation and management of educational material. Constructivism, a perspective that has been studied in communication and education, resonates with our view". Pendapat tersebut menunjukkan bahwa aktivitas belajar siswa akan terjadi dan ditentukan melalui suatu penyediaan dan pengelolaan materi pelajaran. Dengan demikian hal ini merupakan suatu konstruksi yang berkembang menjadi sebuah perspektif penting dalam konteks komunikasi dan konteks pendidikan yang saling mendukung menjadi satu kesatuan.

\section{Peningkatan Aksessibilitas Layanan Pen- didikan dengan "3M-Learning"}

Peningkatan akses layanan pendidikan yang dikembangkan untuk wilayah Jawa Barat Selatan ternyata dapat dilakukan melalui penyediaan akses secara digital dan sistem komunikasi yang dilakukan bersifat online. Sebagaimana dalam temuan penelitian ini bahwa layanan pendidikan bagi peserta didik yang berada di persekolahan dengan letak geografis sangat jauh, ternyata mampu dilakukan. Dengan demikian solusi ini dapat dijadikan sebagai salah satu upaya pemecahan masalah ketercapaian dari rencana strategis pembangunan nasional pendidikan di Indonesia, yakni melalui penajaman salah satu pilar utama, yaitu pilar "akses". Dalam hal ini pilar akses yang diperoleh individu pembelajaran yang berasal dari kelompok masyarakat di wilayah terjauh pun dapat diwujudkan dengan cepat. Sebagai bukti empirik mengenai perbaikan layanan akses pendidikan dan pembelajaran ini, maka berdasarkan temuan data pengakses dan pengguna layanan website "3M-Learning" telah menunjukkan kondisi nyata yang cukup menggembirakan.

Secara keseluruhan, sampai penelitian ini selesai dilakukan, ternyata perkembangan

\section{Jumlah Pengunjung}
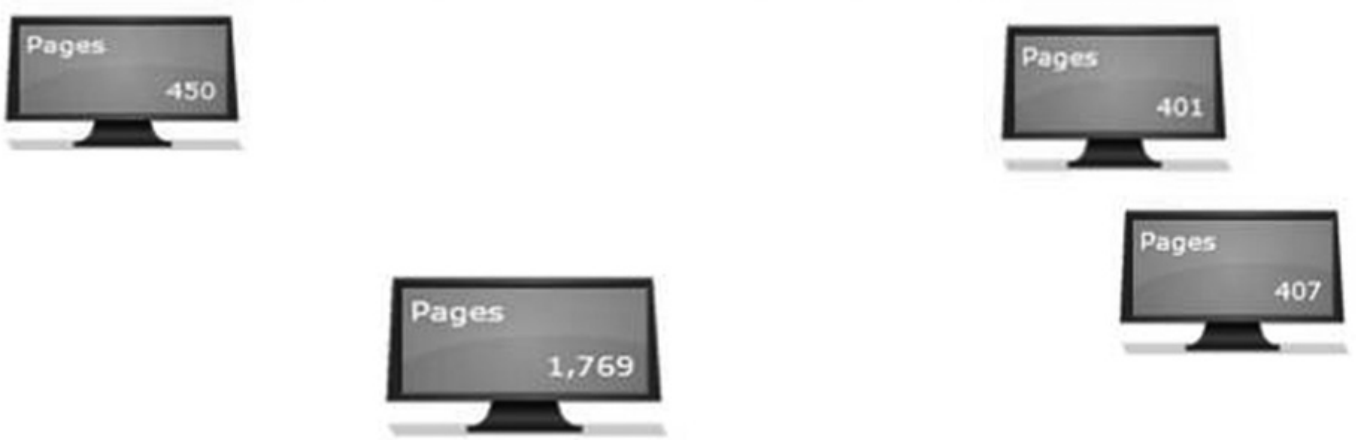

Gambar 12

Record Visitor Harian dan Total Triwulanan Berdasarkan "3M-Learning" yang telah Disempurnakan

(Sumber: http://deni-mlearning.com) 
pengguna dari pengguna website mobile learning dengan nama "3M-Learning" ini secara visualisasi jumlahnya dapat dipantau sebagaimana terlihat pada Gambar 12.

Untuk menunjang aspek sustainabilitas dalam pemanfaatan model pembelajaran "3M-Learning" melalui pemanfaatan akses internet dan kontrol layanan oleh pihak-pihak terkait, maka akan memerlukan suatu sistem kerjasama yang harmonis di antara berbagai pihak. Pihak yang diharapkan mampu menjaga sistem operasional, pengelolaan, updating, dan penyebaran akses sistem informasi sangat diperlukan. Sebagaimana penulis adaptasi dari pendapat Ellis, Gibbs, and Rein dalam Francisco Milton Mendes Neto and Francisco Brasileiro (2007:290), yang menjelaskan bahwa, Collaboration may be seen as the combination of communication, coordination, and cooperation. It appears frequently in the literature as a means to classify collaborative systems or as a basis for groupware development methodologies. In this chapter, we explore the $3 \mathrm{C}$ model as a means to represent a learningware application domain and also as a basis for a system development. While coordinating themselves, people deal with conflicts in such a way as to avoid the loss of communication and cooperation efforts. Cooperation is the joint operation of members of the group in a shared space to complete tasks and generate and manipulate cooperation objects.

Keunggulan dari mobile learning dalam temuan penelitian ini telah memperkuat apa yang telah diteliti oleh Deni Darmawan dan Yuda Gumilar, (2013:26) sebelumnya tentang pengembangan mobile learning pada salah satu mata pelajaran di persekolahan, yaitu: "Based on these opinions, it can be explained that some of the aspects that can influence student learning using a mobile phone, where the students can learn every day, and enjoy free time for study so that students learn is not limited by space and time in school, every subject matter can be distributed to all students by utilizing bluetoot facilities available in the mobile phone, the phone can learn to use collaborative learning, Civics discussion regarding the subject matter of the national legal and judicial systems."

Dari fenomena peningkatan akses yang dilakukan oleh para user terhadap website "3M-Learning" temuan penelitian ini, ternyata indikator utama adalah aspek media dalam bentuk simbol dan gambar yang tersaji dari setiap topik bahan ajar mobile. Terlebih jika dikaitkan dengan kebiasaan atau budaya para guru dan siswa dalam mengenal lebih dekat tentang penggunaan simbol sebagai media komunikasi pembelajaran, ternyata dalam penelitian ini menunjukkan lebih berhasil. Sebagai contoh dalam penyajian judul pokok materi, maka dalam "3M-Learning" ini dalam website nya disesuaikan dengan ciri khas mata pelajaran yang dimaksud seperti pada pokok materi tentang jaringan sel, maka simbol yang dimunculkan adalah gambar jaringan sel jadi tidak hanya teks yang terlihat tetapi juga simbolnya. Kondisi ini sebagaimana dikemukakan oleh Uyu Wahyudin, (2012:1) yang menyatakan bahwa "Media belajar dapat memanfaatkan gambar dan simbol yang terkait dengan budaya...". Keberadaan media belajar dalam pengembangan mobile learning sangat

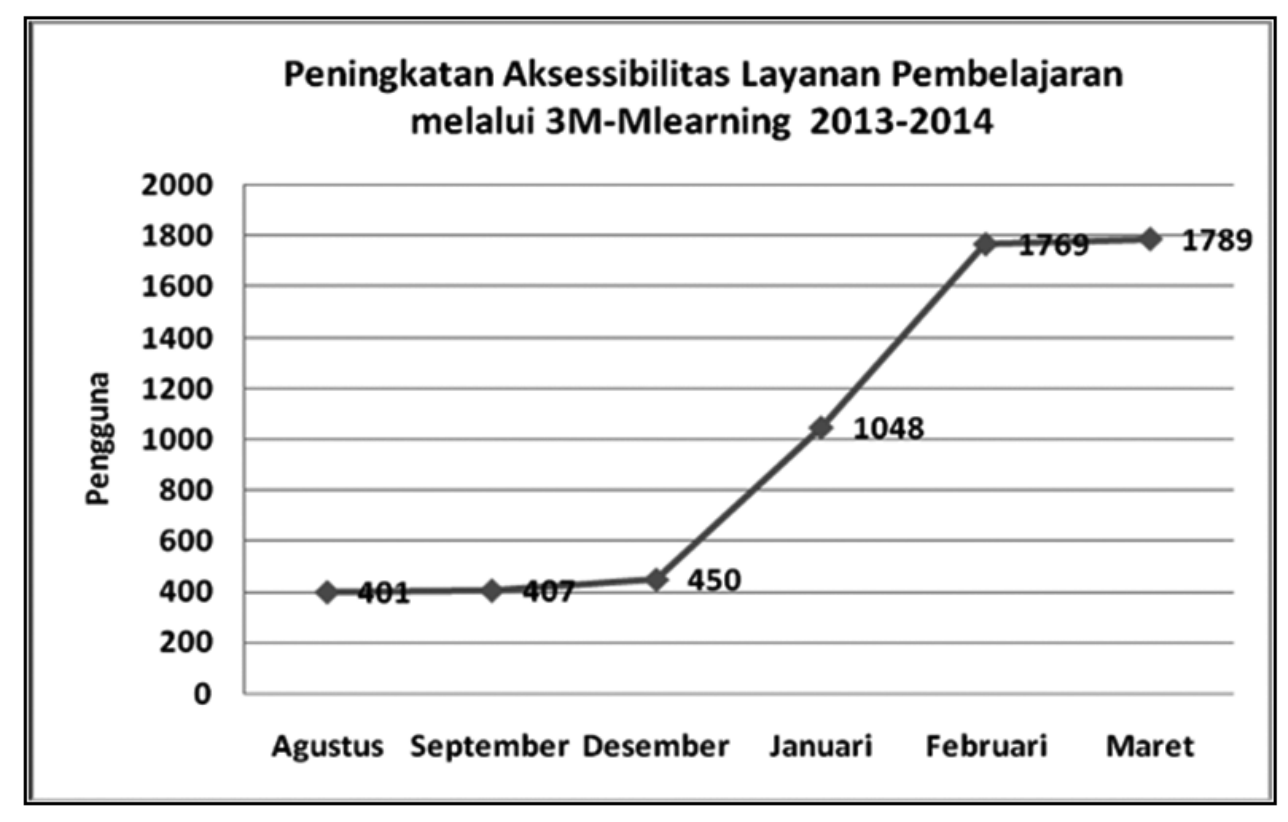

Gambar 13 Peningkatan Aksessibilitas Layanan Pembelajaran

(Sumber: Data analisis laporan penelitian "3M-Learning" oleh Deni Darmawan, 2013) 
dibutuhkan ketika para pengembang bahan ajar akan memberikan simbol atau gambar-gambar yang sesuai dengan perkembangan, dan kebiasaan belajar sehari-hari para siswanya yang tidak terlepas dari aspek budaya. Dengan demikian, dari daya tarik pesan yang dimunculkan dalam bentuk simbol dari website "3M-Learning" ini maka dampaknya telah mampu meningkatkan aksesibilitas para pengguna secara pesat selama 7 bulan terakhir terlihat pada gambar 13.

Jika melihat grafik di atas maka sampai bulan Maret 2014 ini sistem layanan pembelajaran yang telah dibangun dalam bentuk website "3M-Learning" mampu menyentuh pengguna di Jawa Barat Selatan dengan cepat. Dengan demikian tingkat aksesibilitas yang terjadi dapat dinyatakan berdasarkan peningkatan jumlah pengguna dari bulan ke bulan, yaitu mencapai 1789 penguna.

Dari temuan penelitian tentang data peningkatan aksesibilitas ini, maka harapan peneliti akan terus tertuju kepada proses pengembangan yang mewakili lembaga pendidikan tinggi terus menerus melakukan kerjasama dengan pihak terkait lainnya. Kerjasama ini akan terus dilakukan dalam konteks kemitraan dengan ICT Center dari Kabupaten kota di Jawa Barat. Kemitraan ini sangat penting guna menerapkan filosofis orang Jawa Barat yang selalu mampu menyelesaikan permasalahannya melalui penerapan nilai-nilai "gotong royong". Pemikiran yang didukung oleh temuan ini sangat penting dan sangat inovatif mengingat pemanfaatan bahan ajar dalam bentuk inovasi mobile learning ini masih memerlukan pembiasaan secara bersamasama oleh seluruh warga perguruan tinggi, persekolahan, formal serta nonformal dalam ranah pendidikan yang lebih luas.

\section{Simpulan dan Saran}

Berdasarkan tahapan desain dan pengembangan sistem layanan komunikasi pembelajaran jarak jauh dalam bentuk website "3M-Learning" secara online dapat diakses oleh para guru bahkan dosen serta peserta didik. Dengan demikin, hasil penelitian yang berupa produk teknologi "3M-Learning" ini dapat mengatasi kendala komunikasi pembelajaran karena kondisi jarak dan waktu pertemuan yang sulit antara guru dan siswa di wilayah Jawa Barat Selatan. Dalam Pemanfaatannya model ini harus dipayungi oleh kebijakan guru dan siswa, Kepala Sekolah, Pengawas, UPTD, Dinas Pendidikan Kab/kota setempat, yang didukung oleh para dosen di perguruan tinggi.

Secara sosiologis, edukasi, dan industrialisasi, terutama dalam bidang telekomunikasi atau komunikasi bermedia jarak jauh, maka proses produksi "3M-Learning" ini membutuhkan kerjasama kemitraan. Kemitraan tersebut di antaranya menuntut dilakukan oleh peneliti, dosen, guru, sekolah, dinas pendidikan, dan ICT Center bersama dengan PT. Telkom untuk menjadi mitra dalam mensosialisasikan produk "3M-Learning" dalam bentuk handphone, jaringan, layanan akses, yang pada akhirnya akan mampu mendukung capaian aksesibilitas layanan pembelajaran di wilayah Jawa Barat Selatan.

Berdasarkan atas analisis data yang diperoleh melalui pemantauan terhadap website "3M-Learning" dengan alamat akses http://deni-m/earning.com, yang dihasilkan dari penelitian ini telah menunjukkan peningkatan aksesibilitas yang cukup terkendali dan terkontrol oleh para guru dan peserta didik. Peningkatan ini cukup berarti ketika pertama kali online dengan jumlah user yang sebelumnya rendah. Interval peningkatan aksesibilitas untuk meningkatkan layanan pendidikan di persekolahan wilayah Jawa Barat Selatan mengalami peningkatan yang sangat signifikan dari bulan ke bulan.

Dari temuan penelitian ini, maka fenomena aksesibilitas di kemudian hari akan terus menunjukkan kenaikan yang lebih baik. Bahan ajar mobile yang diproduksi oleh pengembang website "3M-Learning" ini telah disesuaikan dengan kebutuhan para pendidik. Bahan ajar yang dikembangkan disesuaikan pula dengan jenjang pendidikan perkembangan kurikulum yang ada. Jika dilihat dari aspek komunikasi pembelajaran jarak jauh maka efektivitas penyampaian pesan komunikasi dari pendidik kepada peserta didik bisa lebih efektif dilakukan. Hal ini terbukti dari hasil analisis atas penggunaan "3M-Learning" yang terus meningkat dari waktu ke waktu.

Dari hasil penelitian ini, maka peneliti berharap bahwa para guru di daerah setidaknya mampu bersaing dengan guru dari perkotaan dengan kemampuan lokal yang dimiliki. Dengan demikian, kebijakan pemerintah dalam mendukung pengembangan bahan ajar dan akses "3M-Learning" ini dapat dilakukan sampai pada tingkat nasional. Selanjutnya bahwa pihak-pihak yang diharapkan dapat menjadi anggota dari "3M-Learning" diantaranya: (1) Dinas Pendidikan Kab/Kota; (2) Sekolah; dan (3) Perguruan Tinggi LPTK. Adapun keberadaan ICT Center di tiap kabupaten dan kota diharapkan mampu menjadi leader dalam mendiseminasikan secara virtual dan massal kepada seluruh persekolahan yang memungkinkan dapat dijangkau oleh akses dan layanan pembelajaran secara online dan mobile.

\section{Daftar Pustaka}

Anita, Rosen., (2008). Learning: Proven Practices and Emerging Technologies to Achieve Real Result. New York: AMACON.

Darmawan, D. (2010). "Biologi Komunikasi melalui Implementasi "Information Communication Technology". Jurnal Sosial dan Pembangunan, 
MIMBAR, Vol 26, No 2 (2010). p.183-204.

Darmawan,D., (2013). Mobile Learning In Increasing Interest And Learning Communication Students. International Journal Enginering Associate. Issue 1. vol.4. p.24-27.

Gall, M, D, Borg Wolter, R., (2009). Operation Research in Education. New York: Mc. Millan. Inc.

Gibson, David, Clrack Aldrich and Prensky, M., (2007). Games and Simulations Online Learning. Hershey: Information Science Publishing.

Milton, Francisco Mendes Neto and Francisco Brasileiro., (2007). Advances in Computer Supported Learning Hershey: Information Science Publishing.

Powel, G. R and Powel, L.D., (2010). Classroom Communication and Dicersity. New York: Routledge.

Roger M. E., (2009), Diffussion of Innovation, $3^{\text {ed }}$, London: The Free Press Collier Macmillan Publisher.

Rosen, A., (2009). Learning: Proven Practices and Emerging Technologies to Achieve Real Result. New York: AMACON.
Ruth, C, C, and Richard, E. M., (2008). E-learning and The Science of Instruction. New York: Pfeiffer. John Wiley \& Sons, Inc.

Wahyudin, U., (2012). Pelatihan Kewirausahaan Berlatar Ekokultural untuk Pemberdayaan Masyarakat Miskin Pedesaan. Jurnal Sosial dan Pembangunan, MIMBAR, Volume 28, No. 1, Tahun 2012, p.1

White, P., (2012). Mobile Access Security and Management. North American: Ericom Software. com.

Willer, M., (2008). Delivering Learning on the Net: the why, what \&how of online education. London and New York: Routledge Falmer. 